\title{
ДОСЛІДЖЕННЯ СИЛЬНИХ ТА СЛАБКИХ СТОРІН, ЗАГРОЗ ТА МОЖЛИВОСТЕЙ ВАНТАЖНИХ ПЕРЕВЕЗЕНЬ ЗАЛІЗНИЧНОГО ТРАНСПОРТУ ПРИ ЗАСТОСУВАННІ МАТРИЦІ SWОТ-АНАЛІЗУ
}

\author{
Ведмідь І.С., аспірант (УкрДАЗТ)
}

Досліджено вантажні перевезення залізниці за допомогою матриці SWOT - аналізу чітко виокремленні наявні сильні та слабкі сторони для визначення шляху удосконалення функціонування вантажних перевезень, як одного з чинників підвищення роботи залізничної галузі України. У статті зроблено висновок щзодо подолання розглянутих проблем в сфері вантажних перевезень з метою уникнути кризові явища в економіці та покращити функціонування иьього сектору галузі.

Ключові слова: ринок вантажних перевезень, матриця SWOT-аналізу, сильні, слабкі сторони, можливості та загрози функціонування вантажних перевезень.

\section{ИССЛЕДОВАНИЕ СИЛЬНЫХ И СЛАБЫХ СТОРОН, УГРОЗ И ВОЗМОЖНОСТЕЙ ГРУЗОВЫХ ПЕРЕВОЗОК ЖЕЛЕЗНОДОРОЖНОГО ТРАНСПОРТА С ПОМОЩЬЮ МАТРИЦЫ SWОТ - АНАЛИЗА}

\author{
Ведмедь И.С., аспирант (УкрГАЖТ)
}

\begin{abstract}
Исследованы грузовые перевозки железной дороги с помощьью матрищы SWOT-анализа, четко выделены имеющиеся сильные и слабые стороны для определения пути усовершенствования функиионирования грузовых перевозок, как одного из факторов улучшения работь железнодорожной отрасли Украины. В статье сделан вывод о преодолении рассматриваемых проблем в сфере грузовых перевозок, с иелью преодоления кризисных явлений в экономике и улучшение функционирование этого сектора отрасли.
\end{abstract}

Ключевые слова: рынок грузовых перевозок, матрица SWOT-анализа, сильные, слабые стороны, возможности и угрозы функционирования грузовых перевозок.

\section{RESEARCH OF STRENGTHS, WEAKNESSES AND OPPORTUNITIES AND THREATS OF RAIL FREIGHT WITH SWOT ANALYSIS MATRIX}

\section{Vedmid I.S., postgraduate student (UkrSURT)}

The article deals with rail freight. Actual strengths and weaknesses were clearly identified with the SWOT analysis to determine the way of rail freight improving as a factor for development of the rail industry of Ukraine. There was made generalization and systematization of the most important problems and advantages of the freight industry. Actual strengths and weaknesses of the internal environment, the most significant opportunities and threats of the external environment for this industry are clearly identified. The paper makes conclusion for solving rail freight problems in question in order to avoid crisis phenomena in the economy and improve operation of this industry sector.

Keywords: freight market, SWOT analysis matrix, strengths, weaknesses, opportunities and threats for rail freight operation.

Постановка проблеми. 3 огляду на те, що залізничний транспорт $є$ стратегічною галуззю вітчизняної транспортної системи, забезпечуючи найбільші обсяги перевезень та володіє найрозвиненішою інфраструктурою, забезпечуючи зовнішньоекономічні зв'язки, необхідні вирішальні заходи відносно стабілізації функціонування основних видів його діяльності, зокрема вантажних перевезень.
Аналіз останніх досліджень $і$ публікацій. У межах окресленої проблематики підвищення ефективності залізничного транспорту суттєвий внесок зробили такі вчені, як Бараш Ю.С., Галабурда В.Г., Дикань В.Л., Дейнека О.Г., Ейтутис Д.Г., Лапидус Б.М., Левицька Л.П., Маркова І.В., Позднякова Л.О., Терьошина Н.П, Чебанова Н.В. та інш. [1-4].

Конкурентним перевагам залізниць на ринку 
вантажних перевезень було приділено увагу Чорного B.B [5], а застосували матрицю SWOT аналізу такі вітчизняні та зарубіжні науковці, як C. Дибб, П.Дойль, Л.В. Балабанова, Г.В. Завгородня [6].

Виділення невирімених частин загальної проблеми. Однак, на жаль, полем творчих пошуків цих видатних науковців $є$ залізничний транспорт в цілому. Ринок транспортних послуг та вантажних перевезень, розглядається як теоретичний аспект i належної уваги щодо практичних заходів удосконалення функціонування вантажних перевезень залізниць України не приділялося.

Метою статmі $€$ дослідження, за допомогою матриці SWOT - аналізу, сильних та слабких сторін, загроз та можливостей вантажних перевезень залізничного транспорту України, як найбільш прибуткової, але нестабільної ланки залізничної галузі за останній час.

Виклад основного матеріалу дослідження. Геополітичне положення України формує її сильний транзитний та експортно-імпортний потенціал, який при раціональному застосуванні, може стати пріоритетним напрямком розвитку національного господарства. Вантажна галузь країни нині знаходиться на етапі застою, суттєво поступаючись країнам Західної Європи. I залізнична галузь цього сектору відзначається негативними тенденціями падіння обсягів перевезення вантажів: у 2014 р. на 12,4 \% менше, ніж у 2013 р. [7].

На нашу думку, актуальним та своєчасним $€$ виокремлення переваг та проблем щодо розвитку вантажних перевезень, з ціллю забезпечити більш високий рівень конкурентоспроможності цієї галузі у теперішні часи. Для цього потрібні не тільки широкомасштабні дослідження факторів впливу та недоліків здійснення вантажної роботи на залізничному транспорті, але i обгрунтовані рекомендації здійснення удосконалення функціонування вантажних перевезень 3 застосуванням передових технологій менеджменту, маркетингу, інвестиційної та інноваційної діяльності тощо.

Подальший розвиток залізниць у результаті створення публічного акціонерного товариства вимагає більш детально визначити нові підходи до споживачів транспортних послуг вантажовласників [8]. Так, незважаючи на те, що вантажна робота на залізницях України й перевезення вантажів у всіх видах сполучень здійснюється в безперебійному звичайному режимі, забезпечуючи потреби національної економіки, в цій сфері діяльності підкреслюється ряд проблем, а саме:

- відсутність державної підтримки, спрямованої на створення умов для оновлення вантажного рухомого складу, його катастрофічна зношеність і тимчасова невідповідність придбання та списання вантажних вагонів;

$$
\text { - функціонування ринку вантажних }
$$

залізничних перевезень в умовах жорсткого стримування тарифів та відсутності їх індексації, що змушує залізничний транспорт дотувати інші галузі економіки;

- недосконалість тарифної політики, яка не забезпечує оптимальної вагонної складової і не містить інвестиційної складової, за рахунок яких можна було б акумулювати кошти на оновлення рухомого складу;

- існування перехресного субсидування збиткових пасажирських перевезень за рахунок вантажних;

- низька якість послуг та обслуговування, що негативно впливає на формування клієнтської аудиторії зі стійкими пріоритетами.

Перелічені проблеми формують тільки внутрішні фактори, які перешкоджають економічному та соціальному розвитку національного господарства [9]. В умовах європейської інтеграції до них додаються і зовнішні фактори, які виражаються в:

- підвищених вимогах міжнародних виробників та транспортних перевізників до якості транспортного обслуговування;

- необхідності відповідності законодавчої системи;

- доцільності розширення сфери діяльності на міжнародному ринку транспортних послуг за рахунок диференціації;

- співвідношення технологічної системи держави з вимогами закордонних країн.

Щоб детально та об'єктивно оцінити ситуацію на ринку вантажних перевезень, виділити найбільш суттєві проблеми та переваги цієі галузі, ми звернулися до SWOT- аналізу, як до наукового методу. За допомогою нього були чітко визначені наявні сильні та слабкі сторони внутрішнього середовища (табл. 1), найбільш значимі можливості та загрози зовнішнього середовища ринку вантажних перевезень залізниці (табл. 2). 3 метою забезпечення подальшого перспективного та стабільного розвитку вантажних перевезень, як одного з чинників підвищення ефективності роботи залізничної галузі України.

Співставлення сильних і слабких сторін функціонування вантажних перевезень залізниці 3 зовнішніми можливостями і загрозами побудовано в матриці SWOT - аналізу (табл. 3). За допомогою розробки цієї матриці, як інструменту стратегічного управління, ми виокремили головні властивості функціонування вантажних перевезень у сьогоденні, щоб в подальшому удосконалити їх роботу, тим самим підвищити ефективність та доходність всієї залізничної галузі України. 
Визначення сильних та слабких сторін ринку вантажних перевезень залізничного транспорту України

\begin{tabular}{|c|c|c|}
\hline Параметри оцінки & Сильні сторони & Слабкі сторони \\
\hline 1 & 2 & 3 \\
\hline Організація & $\begin{array}{l}\text { - правова база транспортної системи країни, } \\
\text { на ряду } 3 \text { вантажними перевезеннями, } \\
\text { встановлена рядом законів та Статутом } \\
\text { залізниць України. }\end{array}$ & - недосконала законодавча база. \\
\hline $\begin{array}{l}\text { Економічний } \\
\text { розвиток }\end{array}$ & $\begin{array}{l}\text { - знижки тарифів на перевезення продукції } \\
\text { гірничо-металургійного та хімічного } \\
\text { комплексів; } \\
\text { - впровадження електронної накладної. }\end{array}$ & $\begin{array}{l}\text { - тарифи на вантажні перевезення } \\
\text { не відповідають європейським та } \\
\text { світовим стандартам, вчасно не } \\
\text { проходять індексацію, що загрожує } \\
\text { економічній безпеки залізниць; } \\
\text { - перехресне субсидування } \\
\text { пасажирських перевезень за } \\
\text { рахунок вантажних; } \\
\text { - інноваційна та інвестиційна } \\
\text { політика ринку вантажних } \\
\text { перевезень знаходиться на стадії } \\
\text { застою. }\end{array}$ \\
\hline $\begin{array}{l}\text { Технологічний } \\
\text { розвиток }\end{array}$ & $\begin{array}{l}\text { - диференціація наявності спеціалізованого } \\
\text { рухомого складу для перевезення, } \\
\text { наприклад, великогабаритних і масових } \\
\text { вантажів; } \\
\text { - достатньо розвинута розгалужена } \\
\text { інфраструктура, можливість доставки } \\
\text { вантажу у будь-яку точки країни; } \\
\text { - велика пропускна спроможність. }\end{array}$ & $\begin{array}{l}\text { - недостатнє оновлення основних } \\
\text { фондів, рухомого складу, значне } \\
\text { фізичне та моральне зношення; } \\
\text { - технологічна } \\
\text { залізничних колій } \text { України та } \\
\text { Європи. } \\
\end{array}$ \\
\hline $\begin{array}{c}\text { Стан навколишнього } \\
\text { середовища }\end{array}$ & $\begin{array}{l}\text { - менший шкідливий вплив на довкілля } \\
\text { порівняно з автомобільним транспортом. }\end{array}$ & $\begin{array}{l}\text { - відсутність розвитку технологій } \\
\text { щодо зменшення забруднення } \\
\text { навколишнього середовища. }\end{array}$ \\
\hline $\begin{array}{l}\text { Ринок праці та } \\
\text { соціальна сфера }\end{array}$ & - наявність кваліфікованої робочої сили. & $\begin{array}{lr}\text { - скорочення штату } & \text { працівників } \\
\text { залізничної галузі; } & \\
\text { - } \quad \text { недостатність } & \text { мотивації } \\
\text { персоналу до змін. } & \end{array}$ \\
\hline
\end{tabular}

Таблиия 2

Визначення можливостей $і$ загроз на ринку вантажних перевезень залізничного транспорту України

\begin{tabular}{|c|c|c|}
\hline Параметри оцінки & Можливості & Загрози \\
\hline Геополітичні фактори & $\begin{array}{l}\text { - побудова міжнародних транспортних } \\
\text { коридорів; } \\
\text { - розвиток транзитного потенціалу } \\
\text { вантажних перевезень. }\end{array}$ & - політична криза. \\
\hline Економічні фактори & $\begin{array}{l}\text { - посилення зовнішньо економічної } \\
\text { діяльності; } \\
\text { - підвищення ефективності роботи } \\
\text { вантажних перевезень. }\end{array}$ & $\begin{array}{l}\text { - економічна криза; } \\
\text { - } \quad \text { недостатнє впровадження } \\
\text { економічних механізмів управління } \\
\text { вантажними перевезеннями; } \\
\text { - стагнація ринку вантажних } \\
\text { перевезень. }\end{array}$ \\
\hline Технологічні фактори & $\begin{array}{l}\text { - розвиток інтермодальних } \\
\text { перевезень; } \\
\text { - удосконалення залізничних колій, } \\
\text { згідно з європейськими стандартами; } \\
\text { - збільшення маси потягів та } \\
\text { впровадження модернізації вагонів. }\end{array}$ & $\begin{array}{lcr}\text { - } \text { ризики } & \text { аварій i } \\
\text { катастроф } & \text { внаслідок } & \text { високого } \\
\text { зношення основних фондів. }\end{array}$ \\
\hline
\end{tabular}

Вісник економіки транспорту і промисловості № 49, 2015 


\begin{tabular}{|c|c|c|}
\hline \multicolumn{3}{|c|}{ Матричя SWOT-аналізу функиіонування вантажних перевезень залізничного транспорту України } \\
\hline \multirow[t]{3}{*}{1} & 2 & 3 \\
\hline & Можливості & Загрози \\
\hline & $\begin{array}{l}\text { 1. Створення публічного акціонерного } \\
\text { товариства «Українські залізниці». } \\
\text { 2. Система знижок для споживачів } \\
\text { транспортних } \\
\text { вантажовласників. } \\
\text { 3. Новітні технології, завдяки яким } \\
\text { формується сильний транзитний та } \\
\text { експортно-імпортний } \\
\text { вантажів. } \\
\text { nотенціал } \\
\end{array}$ & $\begin{array}{l}\text { 1. Політична та економічна криза в } \\
\text { країни. } \\
\text { 2. Стагнація ринку вантажних } \\
\text { перевезень. } \\
\text { 3. Ризики аварій і техногенних } \\
\text { катастроф внаслідок високого } \\
\text { зношення основних фондів. }\end{array}$ \\
\hline \begin{tabular}{l}
\multicolumn{2}{c}{ Сильні сторони } \\
1. Наявність \\
кваліфікаційної робочої \\
сили. \\
$2 . \quad$ Впровадження \\
електронної накладної. \\
$3 . \quad$ Розвиток \\
iнтермодальних \\
вантажних перевезень.
\end{tabular} & 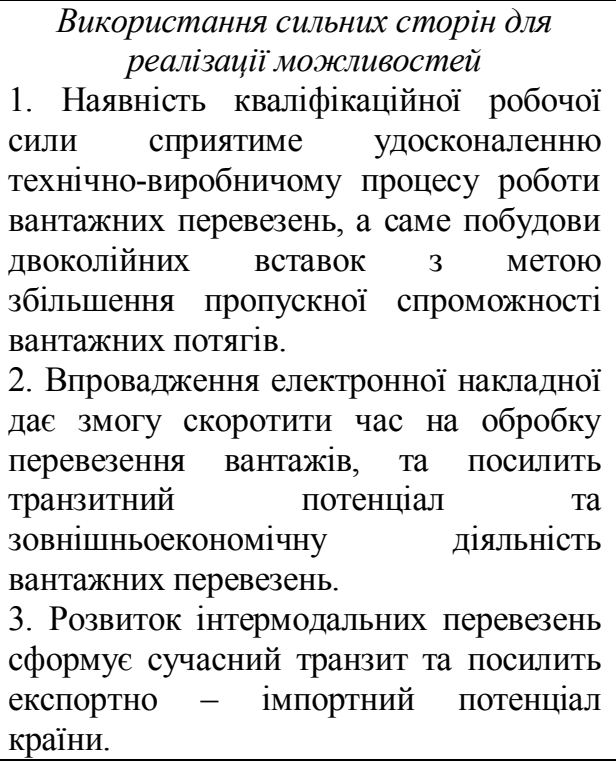 & 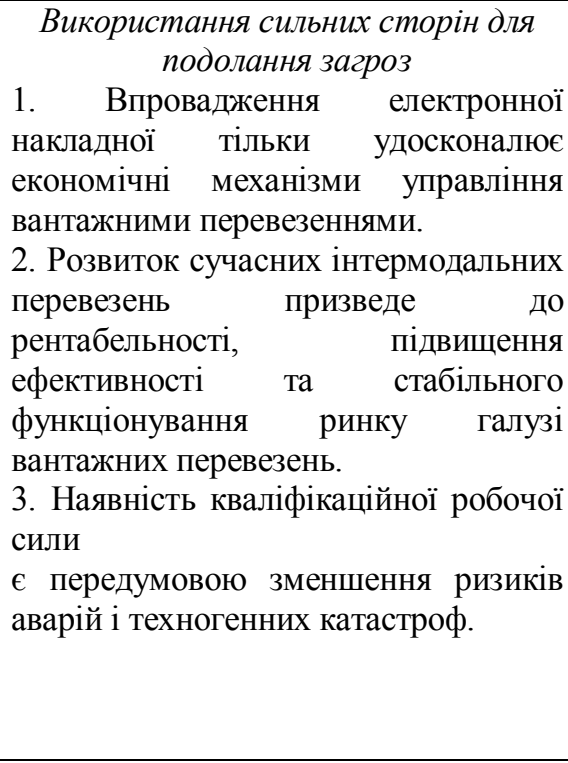 \\
\hline 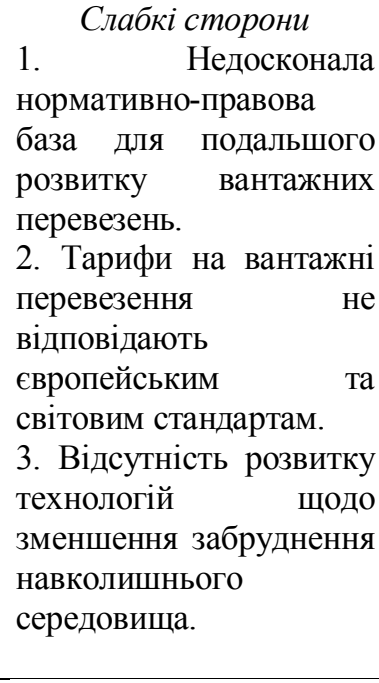 & 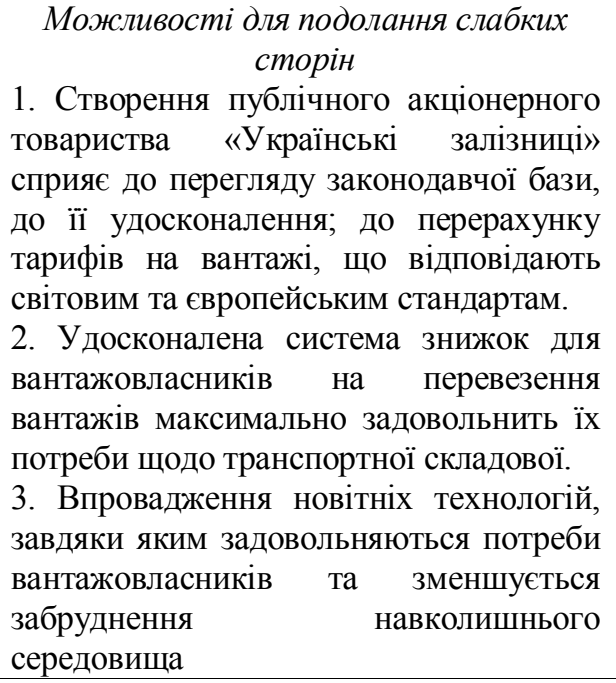 & $\begin{array}{l}\text { Загрози прояву слабких сторін } \\
\text { 1. Політична та економічна криза в } \\
\text { країни посилює погіршення ситуації } \\
\text { щодо законодавчої бази транспорту, } \\
\text { на ряду з вантажними перевезеннями. } \\
\text { 2. Невідповідність європейським та } \\
\text { світовим стандартам тарифів на } \\
\text { вантажі - це один } 3 \text { чинників } \\
\text { стагнації ринку } \\
\text { перевезень. вантажних } \\
\text { 3. Збільшення аварій і техногенних } \\
\text { катастроф провокують забруднення } \\
\text { навколишнього середовища. }\end{array}$ \\
\hline
\end{tabular}

Висновок. У використанні матриці SWOT аналізу є і недоліки: не використовує математичностатистичного оцінювання, факторного аналізу, розрахунків, що і $є$ метою подальшого дослідження транспортної галузі вантажних перевезень. Доцільне використання геополітичного положення
України та можливостей транспортної інфраструктури для міжнародного транзиту, подолання розглянутих проблем в сфері вантажних перевезень, а саме непереривне та стабільне їх здійснення, удосконалення та впровадження нових технологій, впровадження індивідуального підходу 
до вантажовідправників, наявність кваліфікаційної робочої сили, що сприяє удосконаленню технічновиробничому процесу роботи вантажних перевезень, дозволить подальший розвиток економіки та сформує перспективне та стабільне функціонування галузі вантажних перевезень та держави в цілому.

\section{СПИСОК ЛІТЕРАТУРИ}

1. Бараш Ю.С. Управління залізничним транспортом країни. Монографія. / Ю.С. БарашДніпропетровьк, 2006. - 252 с

2. Дикань В.Л. Забезпечення ефективності інноваційної політики [Текст]. Монографія. / В.Л. Дикань-Харків, 2008. - 194 с.

3. Галабурда В.Г. Единая транспортная система./ В.Г.Галабурда. - М.: Транспорт, 1996. $295 \mathrm{c}$

4. Экономика железнодорожного транспорта: Учеб. Для вузов ж.-д./ Н.П.Терешиной,
Б.М.Лапидуса, М.Ф.Трихункова. - М.: УМК МПС России, 2001. -600 с.

5. Чорний В.В. Конкурентні переваги залізниць на ринку вантажних перевезень/ Чорний В.В. /Вісник ЧДТУ «Серія «Економічні науки» Науковий збірник. - 2012. - № 1(56).

6. SWOT-аналіз - основа формування маркетингових стратегій: Навчальний посібник/За ред. Л.В.Балабанової. - 2-ге вид., випр. і доп. - К.: Знання, 2005.-301 с.-(Вища освіта XXI ст.).

7. Офіційний сайт Державної Служби Статистики України [Електронний ресурс]. Режим доступу: http://ukrstat.org

8. Офіційний сайт Укрзалізниці [Електронний ресурс]. Режим доступу: http://www.uz.gov.ua/

9. Кушнир І.Ю. Ефективність вантажних залізничних перевезень України та іiї підвищення в умовах глобалізації. Автореферат дис. канд. наук [Текст] / I.Ю. Кушнир // Харків, УкрДАЗТ. - 2004. $18 \mathrm{c}$.

Рецензент д.е.н., професор УкрДАЗТ Познякова Л.О. Експерт редакційної колегії к.е.н., доцент УкрДАЗТ Полякова О.М.

УДК 338.47:658.8

\title{
ТЕНДЕНЦІЇ РОЗВИТКУ СУЧАСНОЇ ІНФРАСТРУКТУРИ ЗАЛІЗНИЧНОГО ТРАНСПОРТУ НА ОСНОВІ МАРКЕТИНГО-ЛОГІСТИЧНОГО ПІДХОДУ
}

\author{
Копитко В. І. д.е.н., професор, декан факультету Львівської філії (ДНУЗТ)
}

Розглядається маркетинго-логістичний підхід до розвитку сучасної інфраструктури на залізничному транспорті. Пропонується маркетинго-логістичне забезпечення розвитку інфраструктури, щчо буде спряти ефективному управлінню вантажопотоками та пасажиропотоками на залізницях з використанням комплексу взаємопов'язаних інформаційно-управлінських систем. Це дозволить здійснювати технологічний взаємозв'язок із суміжними організаціями транспортного процесу, шзо в подальиому сприятиме створенню інтегрованих транспортно-логістичних ланиюгів 3 урахуванням системних методів управління, спрямованих на досягнення сталого розвитку залізничої галузі. Ращіонально розміщені маркетинго-логістичні центри сприятимуть переходу на зорієнтовану на клієнта модель надання послуг пасажирських $i$ вантажних перевезень на інновачійній основі, використовуючи можливості розвитку державно-приватного партнерства в Украӥні.

Ключові слова: маркетинго-логістичний підхід, інфраструктура залізничного транспорту, оптимізація вантажопотоків та пасажиропотоків, маркетинго-логістичні центри, інновацї, державно-приватне партнерство.

\section{ТЕНДЕНЦИИ РАЗВИТИЯ СОВРЕМЕННОЙ ИНФРАСТРУКТУРЫ ЖЕЛЕЗНОДОРОЖНОГО ТРАНСПОРТА НА ОСНОВЕ МАРКЕТИНГО- ЛОГИСТИЧЕСКОГО ПОДХОДА}

Копитко В. И. д.э.н., профессор, декан факультета Львовского филиала (ДНУЖТ)

Рассматривается маркетингово-логистический подход развития современной инфраструктуры на железнодорожном транспорте. Предлагается маркетинго-логистическое обеспечение развития 